\title{
Contribution of five amino acid residues in the glutathione-binding site to the function of human glutathione transferase P1-1
}

\author{
Mikael WIDERSTEN, Rüdiger H. KOLM, Robert BJÖRNESTEDT and Bengt MANNERVIK* \\ Department of Biochemistry, University of Uppsala, BMC, Box 576, S-751 23 Uppsala, Sweden
}

\begin{abstract}
Five amino acids in proximity to GSH bound in the active-site cavity of human Class Pi glutathione transferase (GST) P1-1 were mutated by oligonucleotide-directed site-specific mutagenesis. The following mutations gave catalytically active mutant proteins with the proper dimeric structure: $\mathrm{Arg}^{14} \rightarrow \mathrm{Ala}, \mathrm{Lys}^{45} \rightarrow \mathrm{Ala}, \mathrm{Gln}^{52} \rightarrow \mathrm{Ala}, \mathrm{Gln}^{65} \rightarrow \mathrm{His}$ and Asp ${ }^{99} \rightarrow \mathrm{Asn}$. The mutation $\mathrm{Gln}^{65} \rightarrow$ Ala was also made, but the protein was not characterized because of its poor catalytic activity. Residues $\mathrm{Arg}^{14}, \mathrm{Lys}^{45}, \mathrm{Gln}^{52}$ and $\mathrm{Gln}^{65}$ all contribute to binding of glutathione, and the substitutions caused an approx. 10-fold decrease in affinity, corresponding to $5 \mathrm{~kJ} / \mathrm{mol}$, except for $\mathrm{Arg}^{14}$, for which the effect was larger. In addition, $\mathrm{Arg}^{14}$ appears to have an important structural role, since the $\mathrm{Arg}^{14} \rightarrow$ Ala mutant demonstrated a significantly lower stability as compared with the wild-type and the other mutant enzymes. Asp ${ }^{99}$ primarily contributes to catalysis rather than to binding. The $k_{\text {cat. }} / K_{\mathrm{m}}$-versus-pH profile for the $\mathrm{Asp}^{99} \rightarrow$ Asn mutant is shifted by $0.5 \mathrm{pH}$ unit in the alkaline direction, and it is proposed that Asp ${ }^{99}$ may participate in proton transfer in the catalytic mechanism. The possibility of redesigning the substrate specificity for GSTs was shown by the fact that the mutant Lys ${ }^{45} \rightarrow$ Ala displayed a higher catalytic efficiency with GSH monoethyl ester than with its natural substrate, GSH.
\end{abstract}

\section{INTRODUCTION}

Studies of the relationship between structure and function form a central theme in enzymology. The goals of such investigations include fundamental insights into mechanisms of catalysis as well as improved understanding of the biological role of the enzymes studied. In the case of the multigene family of glutathione transferases (GSTs), structure-activity studies have been hampered by lack of structural information on the proteins. However, the publication of the crystal structure of a pig lung Class Pi GST (Reinemer et al., 1991) has made more incisive studies possible.

The present investigation involves the human Class Pi GSTP11 [for nomenclature, see Mannervik et al. (1992)], which shares $82 \%$ sequence identity with the homologous Class Pi pig enzyme. The enzyme is a dimeric protein, and the substrate, GSH, has a well-defined binding site, the G-site, in each subunit. On the basis of the three-dimensional structure of the pig enzyme (Reinemer et al., 1991) and the evolutionary conservation of amino acid residues, functional groups in proximity to the GSH molecule in the active site can be identified. These functionalities have now been modified by site-directed mutagenesis in an attempt to understand their contributions to GSH binding and to catalysis.

On the basis of the available structural information, six amino acid residues identified as putative contributors to the G-site were selected for modification in the primary structure of human GSTP1-1 (Kano et al., 1987). [The amino acid residues of human GSTP1-1 are numbered with the initiator methionine as no. 1. The primary structure of the Class Pi pig GST is lacking two residues (Reinemer et al., 1991) as compared with the human enzyme, and the following amino acid residues mutated in the present study have their corresponding pig GST residue numbers given in parentheses: $\operatorname{Tyr}^{8}(7), \operatorname{Arg}^{14}(13), \operatorname{Lys}^{45}(42), \operatorname{Gln}^{52}(49)$, $\mathrm{Gln}^{65}$ (62) and $\mathrm{Asp}^{99}$ (96).] One of them, $\mathrm{Tyr}^{8}$, has already been investigated in a separate study (Kolm et al., 1992). The additional five, namely $\operatorname{Arg}^{14}, \mathrm{Lys}^{45}, \mathrm{Gln}^{52}, \mathrm{Gln}^{65}$ and $\mathrm{Asp}{ }^{99}$, are fully conserved in three additional mammalian Class Pi GSTs for which complete primary structures are available (Suguoka et al., 1985; Hatayama et al., 1990; Dirr et al., 1991). Fig. 1 shows schematically the localization of the six conserved residues around a GSH molecule in the G-site of Class Pi GST. Arg ${ }^{14}$ may interact with the $\alpha$-carboxylate group of the glutamyl moiety of the glutathione molecule, $\mathrm{Lys}^{45}$ may interact with the carboxylate group of the glycine part of glutathione, and $\mathrm{Gln}^{52}, \mathrm{Gln}^{65}$ and

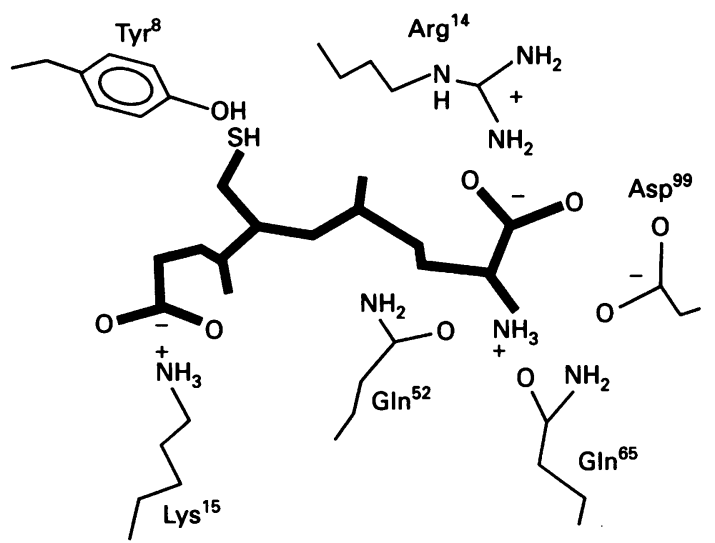

Fig. 1. Schematic representation of the GSH-binding site (G-site) in human Class Pi GSTP1-1

Amino acids in close proximity to GSH bound to the enzyme are indicated (with the numbering based on the initiator Met as no. 1): $\operatorname{Arg}^{14}(13), \operatorname{Lys}^{45}$ (42), $\operatorname{Gln}^{52}(49), \operatorname{Gln}^{65}(62)$ and $\operatorname{Asp}^{99}$ (96); the drawing is based on the published structure of the homologous Class Pi enzyme from pig lung (Reinemer et al., 1991) and the numbers indicated in parentheses refer to the designations of the amino acid residues used for the porcine structure.

Abbreviations used: CDNB, 1-chloro-2,4-dinitrobenzene; GST, glutathione transferase; $L_{50}$, half-saturation concentration of ligand; $I_{50}$, inhibitor concentration giving $50 \%$ inhibition.

* To whom correspondence should be sent. 
$\mathrm{Asp}^{99}$ are in the vicinity of zwitterionic portion of the $\gamma$-glutamyl group of GSH.

\section{MATERIALS AND METHODS}

\section{Mutagenesis of GSTP1 cDNA}

The cDNA encoding the GSTP1 subunit inserted in M13mp18 was mutated in codons $14(\mathrm{Arg} \rightarrow \mathrm{Ala}), 45(\mathrm{Lys} \rightarrow \mathrm{Ala}), 52$ (Gln $\rightarrow$ Ala), 65 (Gln $\rightarrow$ Ala and Gln $\rightarrow$ His) and 99 (Asp $\rightarrow$ Asn), using the procedure of Taylor et al. (1985), by hybridizing the following mutameric oligonucleotides (mis-matched bases underlined) $R 14 A$ : TGC AGC GCA AGC ACC ACG AAC T; $K 45 A$ : GCA GGA GGC TGC CGA GTG AGC C; $Q 52 A$ : CTT GGG GAG CGC CCC GTA TAG; Q65A: GGT ATT GGA CGC GTA CAG GGT; $Q 65 H$ : T GGT ATT GGA GTG GTA CAG GG; D99N: CA GCG GAG GTT CTC CAC GCC G. The mutations were identified by dideoxynucleotide sequencing (Sanger et al., 1977), followed by determination of the entire coding sequence of the cDNA to rule out introduction of unwanted mutations. The mutant GSTP1 cDNAs were subcloned into pKK223-3.

\section{Expression and purification of mutant GSTP1-1 enzymes}

The proteins were expressed from pKK223-3 clones in Escherichia coli JM103 after induction with $0.2 \mathrm{mM}$-isopropyl $\beta$ D-thiogalactopyranoside. Purification was performed as previously described (Widersten et al., 1991) and the homogeneity of the purified mutant enzymes was established by $\mathrm{C}_{4}$ reverse-phase h.p.l.c. (Ostlund Farrants et al., 1987) as well as by isoelectric focusing on precast gels (Pharmacia-LKB-Biotechnology, Uppsala, Sweden) on which the focused proteins were stained with Coomassie Brilliant Blue R-250. Protein concentration was determined by the method of Peterson (1977).

\section{Synthesis of GSH derivatives}

The GSH-ethacrynic acid conjugate was prepared essentially as described by Ploemen et al. (1990). GSH monoethyl ester was synthesized as described by Anderson et al. (1985) and kindly provided by Dr. Marika Eller of our Department.

Table 1. Kinetic parameters of GSTP1-1 and mutant forms in the reaction involving CDNB as electrophilic substrate

Measurements were made in $0.1 \mathrm{M}$-sodium phosphate, $\mathrm{pH} 6.5$, and $2 \%(\mathrm{v} / \mathrm{v})$ ethanol at $30^{\circ} \mathrm{C}$. [GSH] was varied in the range $0.02-$ $6 \mathrm{~mm}$ and [CDNB] was varied in the range $0.02-2 \mathrm{~mm}$. $k_{\text {cat. }}$ values are based on concentration of GSTP1 subunits (using an $M_{\mathrm{r}}$ value of 23400 ). Values are given \pm S.E.M.; relative values as compared with the wild-type values are given below in parentheses.

\begin{tabular}{lcccc}
\hline GST & $\begin{array}{c}k_{\text {eat. }} \\
\left(\mathrm{s}^{-1}\right)\end{array}$ & $\begin{array}{c}K_{\mathrm{m}}^{\mathrm{CDNB}} \\
(\mathrm{mM})\end{array}$ & $\begin{array}{c}K_{\mathrm{m}}^{\mathrm{GSH}} \\
(\mathrm{mM})\end{array}$ & $\begin{array}{c}k_{\text {cat }} / K_{\mathrm{m}}^{\mathrm{GSH}} \\
\left(\mathrm{s}^{-1} \cdot \mathrm{mM}^{-1}\right)\end{array}$ \\
\hline Wild-type & $220 \pm 10$ & $2.6 \pm 0.2$ & $0.5 \pm 0.1$ & 440 \\
& $(1)$ & $(1)$ & $(1)$ & $(1)$ \\
$R 14 A$ & $1.0 \pm 0.2$ & $4.0 \pm 1.0$ & $3.2 \pm 0.9$ & 0.32 \\
& $(0.005)$ & $(1.5)$ & $(6.4)$ & $(0.0007)$ \\
$K 45 A$ & $170 \pm 10$ & $3.8 \pm 0.4$ & $4.3 \pm 0.2$ & 39 \\
& $(0.08)$ & $(1.5)$ & $(8.6)$ & $(0.09)$ \\
$Q 52 A$ & $130 \pm 10$ & $6.2 \pm 0.8$ & $2.8 \pm 0.3$ & 47 \\
& $(0.6)$ & $(2.4)$ & $(5.6)$ & $(0.1)$ \\
$Q 65 H$ & $120 \pm 10$ & $3.4 \pm 0.6$ & $3.4 \pm 0.4$ & 36 \\
& $(0.5)$ & $(1.3)$ & $(6.8)$ & $(0.08)$ \\
$D 99 N$ & $20 \pm 6$ & $3.7 \pm 1.5$ & $0.82 \pm 0.06$ & 26 \\
& $(0.09)$ & $(1.4)$ & $(1.6)$ & $(0.06)$
\end{tabular}

\section{RESULTS}

\section{Physico-chemical characteristics of the mutant enzymes}

Recombinant human GSTP1-1 (wild-type) as well as mutant forms $R 14 A, K 45 A, Q 52 A, Q 65 A$ and $D 99 N$ could all be produced by heterologous expression in $E$. coli. The mutant form $Q 65 A$ showed no catalytic activity in bacterial extracts, even though reasonable quantities of immunoreactive protein could be demonstrated by quantitative e.l.i.s.a. as well as in Western blots (results not shown). As a replacement the mutant $Q 65 H$ was produced. The five mutant proteins finally selected were all enzymically active and could be purified by affinity chromatography on $S$-hexylglutathione-Sepharose 6B (Mannervik \& Guthenberg, 1981). All of the purified proteins were homogeneous, as indicated by isoelectric focusing on gel plates, gel filtration on Superose 12 (Pharmacia-LKB-Biotechnology f.p.l.c. system), and reverse-phase h.p.l.c. (cf. Widersten et al., 1991). The wild-type enzyme was run in parallel, and in the two chromatographic systems the mutant proteins were indistinguishable from the wild-type enzyme. In particular it was noted that in the gel-filtration experiments the proteins gave sharp peaks of elution with no sign of asymmetry that would indicate dissociation of the two protein subunits. The isoelectric points of mutants $R 14 A$ and $K 45 A$ were lower by $0.1 \mathrm{pH}$ unit, and the $\mathrm{pI}$ values of the enzyme from the mutants $D 99 \mathrm{~N}$ and $Q 65 H$ were higher by $0.1 \mathrm{pH}$ unit than that of the wild-type enzyme (pl 4.6). Mutant $Q 52 A$ had the same isoelectric point as the wild-type enzyme.

\section{Functional characterization of the mutant enzymes}

All purified enzymes except mutant $R 14 A$ were stable after purification by the criterion of retained catalytic activity. Mutant $R 14 A$ was unstable and lost catalytic activity with time, even though the protein structure appeared essentially intact as judged from its unchanged chromatographic and electrophoretic behaviour. For this enzyme form, the values given for specific activity, $k_{\text {cat. }}$ and $k_{\text {cat. }} / K_{\mathrm{m}}$ may therefore be underestimated. The values of the specific activity determined with 1-chloro-2,4dinitrobenzene (CDNB) and GSH in the standard assay system were as follows: wild-type, 110: $R 14 A, 0.12 ; K 45 A, 32 ; Q 52 A$, 23; $Q 65 H, 21$; and $D 99 N, 17 \mu \mathrm{mol} \cdot \mathrm{min}^{-1} \cdot \mathrm{mg}^{-1}$.

Table 1 shows kinetic parameters obtained by using CDNB and GSH as substrates. In general, the $K_{\mathrm{m}}$ value for CDNB was only marginally affected by the mutations. The largest increase (2.4-fold) was noted for mutant $Q 52 A$. The $K_{\mathrm{m}}$ value for GSH was increased 5.6-8.6-fold for all mutants except $D 99 \mathrm{~N}$, for which the increase was only 1.6-fold. The $k_{\text {cat. }}$ value was decreased 10 -fold for mutant $D 99 \mathrm{~N}$ and 200 -fold for $R 14 \mathrm{~A}$, whereas it was $50-80 \%$ of the wild-type value for the other mutant forms. The $k_{\text {cat. }} / K_{\mathrm{m}}$ value for $R 14 A$ was decreased dramatically, approximately 1000 -fold, and about 10 -fold for the other mutant forms.

Table 2 lists kinetic parameters obtained with ethacrynic acid as the electrophilic substrate. The effect of mutations on $K_{\mathrm{m}}$ for GSH was qualitatively similar to those measured with CDNB (cf. Table 1). The $K_{\mathrm{m}}$ value for GSH increased by a factor of 9-15, except for mutant $D 99 N$, for which a 1.8-fold increase was observed. The $k_{\text {cat. }}$ values for mutants $K 45 A, Q 52 A$ and $Q 65 H$ increased by a factor of $1.6-1.8$. The $k_{\text {cat }}$ value for mutant $D 99 N$ decreased by a factor of 2.5 , whereas that for mutant $R 14 A$ decreased 6-fold, even if it was difficult to estimate because of the low activity. As a consequence, the $k_{\text {cat. }} / K_{\mathrm{m}}$ values decreased by a factor of 5-7 for all mutants except $R 14 A$, for which the value was even lower by more than an order of magnitude. In addition to the experiments with GSH as the thiol substrate, data were obtained with GSH ethyl ester. Data were collected only for mutant $K 45 A$, in which the functional 
Table 2. Kinetic parameters of GSTP1-1 and mutant forms using GSH or GSH ethyl ester and ethacrynic acid as electrophilic substrate

Measurements were made in $0.1 \mathrm{M}$-sodium phosphate $(\mathrm{pH} 6.5) / 2.5 \%(\mathrm{v} / \mathrm{v})$ ethanol, using variable concentrations $(0.007-2.0 \mathrm{mM})$ of thiol substrate in the presence of a saturating concentration $(0.3 \mathrm{mM})$ of ethacrynic acid. Values are given as means \pm S.E.M. (cf. Table 1$)$.

\begin{tabular}{|c|c|c|c|c|c|c|}
\hline \multirow[b]{2}{*}{ GST } & \multicolumn{3}{|c|}{ GSH } & \multicolumn{3}{|c|}{ GSH ethyl ester } \\
\hline & $\begin{array}{l}k_{\text {cati }} \\
\left(\mathrm{s}^{-1}\right)\end{array}$ & $\underset{(\mathrm{mm})}{K_{\mathrm{m}}}$ & $\begin{array}{c}k_{\text {cat. }} / K_{\mathrm{m}} \\
\left(\mathrm{s}^{-1} \cdot \mathrm{mM}^{-1}\right)\end{array}$ & $\begin{array}{l}k_{\text {cat. }} \\
\left(\mathrm{s}^{-1}\right)\end{array}$ & $\begin{array}{c}K_{\mathrm{m}} \\
(\mathrm{mM})\end{array}$ & $\begin{array}{c}k_{\text {cat }} / K_{\mathrm{m}} \\
\left(\mathrm{s}^{-1} \cdot \mathrm{mm}^{-1}\right)\end{array}$ \\
\hline Wild-type & $\begin{array}{l}0.60 \pm 0.035 \\
\text { (1) }\end{array}$ & $\begin{array}{c}0.078 \pm 0.014 \\
\text { (1) }\end{array}$ & $\begin{array}{l}7.7 \\
(1)\end{array}$ & $\begin{array}{l}0.34 \pm 0.05 \\
\text { (1) }\end{array}$ & $\begin{array}{c}0.43 \pm 0.14 \\
\quad(1)\end{array}$ & $\begin{array}{l}0.8 \\
(1)\end{array}$ \\
\hline$R 14 A^{*}$ & $\begin{array}{c}0.1 \pm 0.05 \\
(0.2)\end{array}$ & $\begin{array}{l}1.2 \pm 1 \\
(15)\end{array}$ & $\begin{array}{c}0.08 \\
(0.01)\end{array}$ & - & - & - \\
\hline$K 45 A$ & $\begin{array}{c}0.95 \pm 0.06 \\
(1.6)\end{array}$ & $\begin{array}{l}0.82 \pm 0.12 \\
\quad(11)\end{array}$ & $\begin{array}{c}1.2 \\
(0.2)\end{array}$ & $\begin{array}{c}1.96 \pm 0.25 \\
(5.8)\end{array}$ & $\begin{array}{c}1.32 \pm 0.31 \\
(3.1)\end{array}$ & $\begin{array}{l}1.5 \\
(1.9)\end{array}$ \\
\hline$Q 52 A$ & $\begin{array}{c}1.06 \pm 0.08 \\
(1.8)\end{array}$ & $\begin{array}{c}0.70 \pm 0.12 \\
(9)\end{array}$ & $\begin{array}{l}1.5 \\
(0.2)\end{array}$ & - & - & - \\
\hline$Q 65 H$ & $\begin{array}{c}1.05 \pm 0.04 \\
(1.8)\end{array}$ & $\begin{array}{l}0.83 \pm 0.083 \\
(11)\end{array}$ & $\begin{array}{c}1.3 \\
(0.2)\end{array}$ & - & - & - \\
\hline$D 99 N$ & $\begin{array}{c}0.24 \pm 0.01 \\
(0.4)\end{array}$ & $\begin{array}{c}0.14 \pm 0.022 \\
\quad(1.8)\end{array}$ & $\begin{array}{c}1.7 \\
(0.2)\end{array}$ & - & - & - \\
\hline
\end{tabular}

* The $R 14 A$ mutant was unstable, hence the values determined for this mutant are uncertain, but are included for completeness.

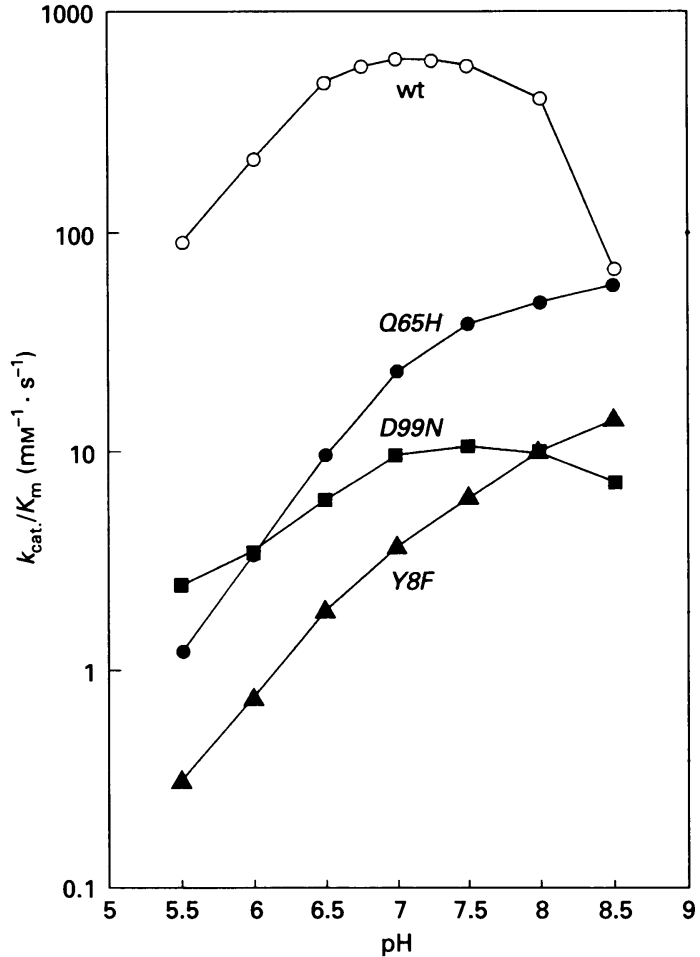

Fig. 2. Dependence of $k_{\mathrm{cat} .} / K_{\mathrm{m}}$ on $\mathrm{pH}$ for wild-type (wt) and mutant forms of human Class Pi GSTP1-1

The values were obtained by varying the concentration of GSH at high fixed levels of the electrophilic substrate CDNB (1 mM) using $0.1 \mathrm{M}$-sodium phosphate buffer. Symbols: $\bigcirc$, wild-type;, mutant $Q 65 H ; \mathbf{\square}$, mutant $D 99 N ; \mathbf{\Lambda}$, mutant $Y 8 F$.

ammonium group expected to interact with the glycine residue of glutathione is removed (Fig. 1). It was found that mutant $K 45 \mathrm{~A}$ had a 6-fold increased $k_{\text {cat. }}$ and a 3-fold increased $K_{\mathrm{m}}$ value for GSH ethyl ester as compared with the normal thiol substrate. Thus the $k_{\text {cat. }} / K_{\mathrm{m}}$ value increased 2-fold.

The $\mathrm{pH}$-dependence of $k_{\text {cat }} / K_{\mathrm{m}}$ was determined for mutant forms $Q 65 H$ and $D 99 N$ (Fig. 2) and compared with values
Table 3. Binding and inhibition parameters for GSTP1-1 mutant forms

Direct binding measurements were made by measuring quenching of the intrinsic tryptophan fluorescence (excitation at $280 \mathrm{~nm}$, emission at $338 \mathrm{~nm}$ ) of the enzyme ( $2.5 \mu \mathrm{M}$ subunit) in $0.1 \mathrm{M}$-sodium phosphate buffer $\mathrm{pH} 7.2$, at ambient temperature $\left(20^{\circ} \mathrm{C}\right)$. The half-saturation concentration of thiol $\left(L_{50}\right)$ was determined by fitting the $2: 2$ rational function to the experimental data (Bardsley et al., 1989). Inhibition parameters $\left(I_{50}\right.$ and $\left.K_{\mathrm{i}}\right)$ were determined in the standard assay system including $0.1 \mathrm{M}$-sodium phosphate, $\mathrm{pH} 6.5$, and $1 \mathrm{mM}$ CDNB. $I_{50}$ is the concentration of inhibitor giving $50 \%$ inhibition in the presence of $1 \mathrm{~mm}-\mathrm{GSH}$, and $K_{\mathrm{i}}$ is the inhibition constant estimated by measurements at different GSH concentrations and extrapolation to zero GSH concentration (i.e. the inhibition constant corresponding to competitive inhibition).

\begin{tabular}{|c|c|c|c|c|}
\hline \multirow[t]{2}{*}{ Substrate... } & \multirow{2}{*}{$\begin{array}{c}\mathrm{GSH} \\
L_{50} \\
(\mathrm{mM})\end{array}$} & \multirow{2}{*}{$\begin{array}{c}\begin{array}{c}\text { GSH } \\
\text { ethyl ester }\end{array} \\
L_{50} \\
(\mathrm{mM})\end{array}$} & \multicolumn{2}{|c|}{$\begin{array}{l}\text { GSH-ethacrynic } \\
\text { acid conjugate }\end{array}$} \\
\hline & & & $\begin{array}{c}I_{50} \\
(\mu \mathrm{M})\end{array}$ & $\begin{array}{c}K_{\mathrm{i}} \\
(\mu \mathrm{M})\end{array}$ \\
\hline Wild-type & $\begin{array}{l}0.078 \\
\text { (1) }\end{array}$ & $\begin{array}{l}0.84 \\
(1)\end{array}$ & $\begin{array}{c}5 \\
(1)\end{array}$ & $\begin{array}{c}1 \\
(1)\end{array}$ \\
\hline$R 14 A$ & $\begin{array}{c}0.8 \\
(10)\end{array}$ & - & $\begin{array}{l}>100 \\
(>20)\end{array}$ & - \\
\hline$K 45 A$ & $\begin{array}{l}0.82 \\
(11)\end{array}$ & $\begin{array}{l}7.92 \\
(9.4)\end{array}$ & $\begin{array}{l}3 \\
(0.6)\end{array}$ & $\begin{array}{c}1 \\
(1)\end{array}$ \\
\hline$Q 52 A$ & $\begin{array}{l}1.43 \\
(18)\end{array}$ & - & $\begin{array}{l}50 \\
(10)\end{array}$ & $\begin{array}{c}40 \\
(40)\end{array}$ \\
\hline$Q 65 H$ & $\begin{array}{r}0.61 \\
(7.8)\end{array}$ & - & $\begin{array}{l}19 \\
(3.8)\end{array}$ & $\begin{array}{c}9 \\
(9)\end{array}$ \\
\hline$D 99 N$ & $\begin{array}{l}0.039 \\
(0.5)\end{array}$ & - & $\begin{array}{c}4 \\
(0.8)\end{array}$ & $\begin{array}{c}1 \\
\text { (1) }\end{array}$ \\
\hline
\end{tabular}

previously determined for the wild-type enzyme and mutant $Y 8 F$ (Kolm et al., 1992). The pH profile for mutant $Q 65 H$ was qualitatively similar to that of $Y 8 F$ and could be described by a simple protolysis with a $\mathrm{p} K_{\mathrm{a}}$ value of 7.2. Mutant $D 99 \mathrm{~N}$ gave a $\mathrm{pH}$ profile similar to that of the wild-type enzyme, with a $\mathrm{pH}$ optimum at $\mathrm{pH} 7.5$ and apparent $\mathrm{p} K_{\mathrm{a}}$ values of 6.4 and 8.7.

The affinity of the different enzyme forms for GSH and GSH derivatives was quantified by direct binding experiments as well as by inhibition studies (Table 3 ). In agreement with $K_{\mathrm{m}}$ values, 
the binding parameter (the half-saturation concentration of thiol; $L_{50}$ ) for glutathione was increased by a factor of 8-18-fold for mutants $R 14 A, K 45 A, Q 52 A$ and $Q 65 H$. In contrast, mutant $D 99 \mathrm{~N}$ demonstrated a 2-fold increased affinity for GSH as compared with the wild-type enzyme. GSH ethyl ester binding was measured only for mutant $K 45 \mathrm{~A}$, and was found to have a 9-fold loss of binding affinity by the mutation. In addition, the conjugate of GSH and ethacrynic acid was used for inhibition experiments, in which CDNB served as the electrophilic substrate. The inhibitor concentration giving $50 \%$ inhibition $\left(I_{50}\right)$ as well as $K_{1}$ values were determined (Table 3 ). Two of the mutant forms, $K 45 A$ and $D 99 N$, displayed the same binding affinity as the wildtype enzyme. Mutant R14A demonstrated a drastically reduced affinity for the GSH conjugate.

\section{DISCUSSION}

The results from the present as well as from the previous (Kolm et al., 1992) investigation of human GSTP1-1 clearly demonstrate that all of the amino acid residues of the G-site depicted in Fig. 1 contribute to the catalytic activity of the enzyme. Several studies involving GSTs of Class Pi (Kolm et al., 1992; Kong et al., 1992), Class Alpha (Stenberg et al., 1991) and Class Mu (Liu et al., 1992) consistently indicate that an evolutionarily conserved $\mathrm{Tyr}$ residue, corresponding to $\mathrm{Tyr}^{8}$ in human GSTP1-1, participates in catalysis by forming a hydrogen bond between the phenolic hydroxy group and the sulphur atom of GSH bound at the active site. Its main contribution is to catalysis rather than to binding of GSH or the electrophilic second substrate. In contrast, residues $\mathrm{Arg}^{14}, \mathrm{Lys}^{45}, \mathrm{Gln}^{52}$ and $\mathrm{Gln}^{65}$ all appear to contribute significantly to binding of the GSH molecule. Removal of the functional group in the side chain in all these residues lead to an approx. 10-fold decrease in binding affinity, equivalent to $5 \mathrm{~kJ} / \mathrm{mol}$, as demonstrated by direct equilibrium-binding studies (Table 3 ) as well as by kinetic data such as $K_{\mathrm{m}}$ values (Tables 1 and 2) and $K_{\mathrm{f}}$ values (Table 3). The same parameters indicate that Asp ${ }^{99}$ does not contribute significantly to binding of GSH. In contrast, this residue appears to be important for the catalytic process, as evidenced by the decreased $k_{\text {cat. }}$ value in mutant $D 99 N$ (Tables 1 and 2).

Arg $^{14}$ appears to have an important structural role in the protein, since removal of the side chain (mutant R14A) leads to a protein that is significantly less stable than the wild-type enzyme.

The GSH conjugate of ethacrynic acid is a reasonably strong inhibitor of GSTP1-1 (Table 3; see also Ploemen et al., 1990). The binding strength of the inhibitor was estimated by determination of $I_{50}$ and $K_{\mathrm{i}}$ values. In essential agreement with the results of GSH binding, mutant forms $R 14 A, Q 52 A$ and $Q 65 H$ displayed a marked loss of binding affinity for the conjugate. Mutant RI4A displayed a particularly low affinity for the inhibitor. In contrast with the results obtained with GSH, mutant $K 45 \mathrm{~A}$ did not show any loss of binding affinity for the conjugate. The latter result indicates that the binding of the inhibitor is governed to a large extent by the ethacrynic acid moiety of the GSH conjugate.

The dependence of $k_{\text {cat. }} / K_{\mathrm{m}}$ on $\mathrm{pH}$ has previously been studied for the wild-type enzyme and for mutant $Y 8 F$ (Kolm et al., 1992). The wild-type enzyme displays an optimum at $\mathrm{pH} \mathrm{7.0,} \mathrm{whereas}$ the mutant $Y 8 F$ shows an activity that monotonously increases with $\mathrm{pH}$ in the range investigated. Similar studies were made on mutant forms $Q 65 H$ and $D 99 N$ in the present investigation (Fig. 2). The $\mathrm{pH}$-activity profile for mutant $D 99 \mathrm{~N}$ is similar to that of the wild-type enzyme even if the $k_{\text {cat. }} / K_{\mathrm{m}}$ values are significantly lower and the $\mathrm{pH}$ optimum is shifted by 0.5 unit to $\mathrm{pH}$ 7.5. This change of the $\mathrm{pH}$ optimum is apparently related to removal of the negative charge of Asp ${ }^{99}$, which will change the electrical potential in the active-site region. In the wild-type enzyme, Asp ${ }^{99}$ may participate in proton release in the catalytic process, a proposal consistent with the finding that CDNB conjugation (generating a proton) is more strongly affected than ethacrynic acid conjugation (no net release of a proton) (cf. Tables 1 and 2).

Mutant $Q 65 H$ demonstrated an activity profile similar to that of mutant $Y 8 F$ (Fig. 2). However, the explanations for the curve shapes are quite different for the two mutant forms. In $Y 8 F$ the basic limb is missing that, in the wild-type enzymes, shows decreasing activity with increasing $\mathrm{pH}$. The loss of activity at high $\mathrm{pH}$ values is ascribed to ionization of the phenolic hydroxy group of $\mathrm{Tyr}^{8}$ in the wild-type enzyme, a group that is missing in mutant $Y 8 F$. In mutant $Q 65 H$, however, $\mathrm{Tyr}^{8}$ can still ionize as in the wild-type enzyme and the $k_{\text {cat. }} / K_{\mathrm{m}}$ value at $\mathrm{pH} 8.5$ is not significantly different from that of the wild-type enzyme (Fig. 2). However, at lower $\mathrm{pH}$ values the difference in activity between the wild-type enzyme and mutant $Q 65 H$ becomes very pronounced, differing by a factor of approx. 100 at $\mathrm{pH} 5.5$. The difference at lower $\mathrm{pH}$ values is dependent on protonation of the imidazole group of $\mathrm{His}^{65}$ in the mutant enzyme. The carboxamido side chain of $\mathrm{Gln}^{65}$ in the wild-type enzyme probably forms a hydrogen bond to the $\alpha$-ammonium group of the $\gamma$-glutamyl residue of GSH bound to the enzyme, and introduction of a positively charged imidazolium group in mutant $Q 65 H$ is expected to decrease the affinity for GSH. The side-chain of His occupies approximately the same space as the side chain of Gln, and in unprotonated form the imidazole ring has similar hydrogen-bonding potential to the carboxamido group of $\mathrm{Gln}^{65}$.

In a wider perspective, modification of the structure of the active site of an enzymes is an approach towards designing proteins with new activities. Thus GSTP1-1 mutant $K 45 A$ was constructed with an aim of not only assessing the significance of the positive charge of $\mathrm{Lys}^{45}$ in binding a carboxylate group of GSH, but also to find out if an enzyme with enhanced activity against GSH ethyl ester could be obtained. The data in Table 2 show that the catalytic efficiency, expressed as $k_{\text {cat. }} / K_{\mathrm{m}}$, is increased 2-fold in the mutant $K 45 A$ as compared with the value for the wild-type enzyme, a moderate but significant effect. The major consequence of the mutation is an increase in the $k_{\text {cat. }}$ value, suggesting that rate-contributing release of the GSH conjugate is facilitated by the loss of the ionic bond between the glycine carboxylate group of GSH and the ammonium group of Lys $^{45}$. This result shows that there is potential for redesigning the G-site in order to accommodate derivatives of GSH as alternative substrates.

In conclusion, six amino acid residues in the GSH-binding site of human GSTP1-1 have now been shown by functional studies to participate in the enzymic action. $\mathrm{Tyr}^{8}$ (Kolm et al., 1992) and Asp ${ }^{99}$ primarily contribute to the catalytic process as such $\left(k_{\text {cat. }}\right.$ ), whereas $\mathrm{Arg}^{14}$, $\mathrm{Lys}^{45}, \mathrm{Gln}^{52}$ and $\mathrm{Gln}^{65}$ function in the binding of GSH.

We thank Dr. Ulf Ragnarsson and Dr. Marika Eller at our Department for synthesizing GSH monoethyl ester and making the compound available for the study. This work was supported by the Swedish Council for Engineering Sciences, the Swedish Natural Science Research Council and the Carl Tryggers Stiftelse. R. B. was a recipient of a fellowship from Sven and Lilly Lawski's fund.

\section{REFERENCES}

Anderson, M. E., Powrie, F., Puri, R. N. \& Meister, A. (1985) Arch. Biochem. Biophys. 239, 538-548

Bardsley, W. G., McGinlay, P. B. \& Roig, M. G. (1989) J. Theor. Biol. 139, 85-102

Dirr, H. W., Mann, K., Huber, R., Ladenstein, R. \& Reinemer, P. (1991)

Eur. J. Biochem. 196, 693-698

Hatayama, I., Satoh, K. \& Sato, K. (1990) Nucleic Acids Res. 18, 4606 
Kano, T., Sakai, M. \& Muramatsu, M. (1987) Cancer Res. 47, 5626-5630 Kolm, R. H., Sroga, G. \& Mannervik, B. (1992) Biochem. J., in the press Kong, K.-H., Nishida, M., Inoue, H. \& Takahashi, K. (1992) Biochem. Biophys. Res. Commun. 182, 1122-1129

Liu, S., Zhang, P., Xinhua, J., Johnson, W. W., Gilliland, G. L. \& Armstrong, R. N. (1992) J. Biol. Chem. 267, 4296-4299

Mannervik, B. \& Guthenberg, C. (1981) Methods Enzymol. 77, 231-235 Mannervik, B., Awasthi, Y. C., Board, P. G., Hayes, J. D., Di Ilio, C., Ketterer, B., Listowsky, I., Morgenstern, R., Muramatsu, M., Pearson, W. R., Pickett, C. B., Sato, K., Widersten, M. \& Wolf, C. R. (1992) Biochem. J. 282, 305-306

Ostlund Farrants, A.-K., Meyer, D. J., Coles, B., Southan, C., Aitken, A., Johnson, P. J. \& Ketterer, B. (1987) Biochem. J. 245, 423-428

Peterson, G. L. (1977) Anal. Biochem. 83, 346-356

Received 14 April 1992/7 May 1992; accepted 11 May 1992
Ploemen, J. H. T. M., van Ommen, B. \& van Bladeren, P. J. (1990) Biochem. Pharmacol. 40, 1631-1635

Reinemer, P., Dirr, H. W., Ladenstein, R., Schäffer, J., Gallay, O. \& Huber, R. (1991) EMBO J. 10, 1997-2005

Sanger, F., Nicklen, S. \& Coulson, A. R. (1977) Proc. Natl. Acad. Sci. U.S.A. 74, 5463-5467

Stenberg, G., Board, P. G. \& Mannervik, B. (1991) FEBS Lett. 293, 153-155

Suguoka, Y., Kano, T., Okuda, A., Sakai, M., Kitagawa, T. \& Muramatsu, M. (1985) Nucleic Acids Res. 13, 6049-6057

Taylor, J. W., Ott, J. \& Eckstein, F. (1985) Nucleic Acids Res. 13, 8765-8785

Widersten, M., Pearson, W. R., Engström, Å. \& Mannervik, B. (1991) Biochem. J. 276, 519-524 